Angelika Lament-Kosińska

Instytut Zabytkoznawstwa i Konserwatorstwa, Wydział Sztuk Pięknych UMK w Toruniu

\title{
Zarys historii, stan zachowania i przyczyny zniszczeń malowideł ściennych Wacława Taranczewskiego w kościele pw. św. Anny w Poznaniu
}

\section{Wstęp}

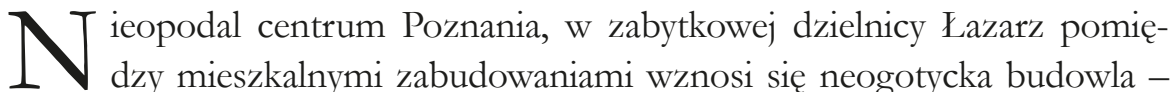
niegdyś ewangelicki kościół pw. Chrystusa ${ }^{1}$, dzisiaj kościół katolicki pw. św. Anny. Jednym z nieodłącznych elementów wystroju jego wnętrza są wykonane niemal 60 lat temu polichromie zdobiace ściany prezbiterium. Choć łączą się z nazwiskiem jednego z najznamienitszych XX-wiecznych polskich artystów, ich przetrwanie od kilku lat jest poważnie zagrożone.

\section{Historyczny rys kościoła i malowideł}

Potrzeba wzniesienia ewangelickiej budowli sakralnej na Łazarzu narastała od końca XIX wieku. Wiązała się z licznymi niedogodnościami prote-

1 O. Kiec, Ewangelicka Parafia Chrystusa na Lazarzu 1902-1945, [w:] Kronika Miasta Poznania. Świety Łazary, red. J. Wiesiołowski, Poznań 1998, cz. 3, s. 94. 
stantów zamieszkujących tę dzielnicę, głównie pochodzenia niemieckiego, którzy początkowo próbowali sami zorganizować pomieszczenie do odprawiania nabożeństw, a później zmuszeni byli dojeżdżać do kościołów, które z Lazarzem nie były skomunikowane ${ }^{2}$. Po wielu trudnościach udało się pozyskać odpowiedni plac oraz fundusze na rozpoczęcie budowy. Świątynia według projektu pracowni Oskara Hossfelda z Berlina przyjmować miała charakter budowli w stylu północnoniemieckiego gotyku³. Budowę trójnawowego i trójprzęsłowego kościoła z cegły i granitowych bloków, na planie krzyża łacińskiego, rozpoczęto w 1904 roku pod kierownictwem Schwanna i Pulnitza ${ }^{4}$. Świątynia została oddana do użytku trzy lata później, w roku $1907^{5}$.

Podczas planowania budowli pominięto postulaty o ulokowanie kościoła tak, aby jego apsyda zwrócona była w kierunku wschodnim. Ostateczne zorientowanie prezbiterium $\mathrm{w}$ kierunku północno-zachodnim traktowano później jako pewien mankament, ze względu na wynikająca z tego potrzebę doświetlania wnętrza ${ }^{6}$. Wyposażenie świątyni, podobnie jak jej projekt i budowę, powierzono artystom i rzemieślnikom niemieckiego pochodzenia. Polichromie ścienne wykonane wówczas we wnętrzu przez berlińskiego malarza, znanego jedynie z nazwiska - Feya, zachowały się do końca II wojny światowej?

Wnętrze kościoła uległo znacznym zmianom po 1945 roku. Wtedy to właśnie po ucieczce z Poznania większości Niemców oraz duchowych przywódców ich Kościoła ${ }^{8}$, świątynia została przejęta przez Kościół katolicki, który erygował w tym miejscu w 1947 roku parafię pw. św. Anny. Przebudowa kościoła prowadzona w latach 1953-1957 wniosła do wnętrza takie zmiany, jak usunięcie charakterystycznych dla kościołów ewangelic-

2 Ibidem, s. 87.

3 Ibidem, s. 92.

4 W. Starzycki [zał.], Biała karta kościoła pw. św. Anny w Poznaniu, w zb. Miejskiego Konserwatora Zabytków w Poznaniu (dalej: MKZ), Poznań 1979.

5 O. Kiec, op. cit., s. 94.

6 Ibidem, s. 94.

7 J. i J. Sobaczykowie, Kościół św. Anny, mps w zb. MKZ, Poznań 1989, s. 10.

8 Miało to miejsce w styczniu 1945 roku, [zob.:] O. Kiec, op. cit., s. 103. 
kich empor z naw bocznych oraz starej polichromii autorstwa niemieckiego malarza?.

Pod koniec gruntownego remontu kościoła postanowiono powierzyć aranżację nowego wystroju malarskiego uznanemu już wówczas artyście i pedagogowi - profesorowi Wacławowi Taranczewskiemu. Miał on w tamtym czasie w swoim dorobku już prawie dwadzieścia innych monumentalnych realizacji, głównie o tematyce sakralnej i przeważnie na ziemiach Wielkopolski, w tym również uznawaną za najpełniejsze jego monumentalne dzieło - aranżację wnętrza kościoła pw. Najświętszej Marii Panny na Ostrowie Tumskim w Poznaniu ${ }^{10}$.

Choć od 1950 roku artysta mieszkał już na stałe w Krakowie ${ }^{11}$, jego związek z Poznaniem, w którym spędził niemal 50 lat swojego życia, wciąż pozostawał bardzo silny. Wraz z dwójką innych poznańskich artystów - Elżbietą Czeczot-Werc i Wacławem Twardowskim - oraz pochodzącą z Sopotu Haliną Bajońską ${ }^{12}$ wykonał on w 1956 roku polichromie zdobiące ściany i sklepienie kościoła.

W prezbiterium pojawił się wówczas cykl szesnastu scen z życia św. Anny i św. Joachima oraz z życia Najświętszej Marii Panny (il. 4). Przedstawienia ujęto $\mathrm{w}$ prostokątne ramy i skomponowano je pasowo w dwóch rzędach. Obrazy podzielono po cztery na obie ściany po lewej stronie oraz adekwatnie po prawej stronie ołtarza głównego. Cały cykl czytamy od lewej do prawej i na zmianę od góry do dołu. W górnym rzędzie, najbardziej na lewo, namalowano scenę ukazującą św. Joachima z pasterzami. Poniżej znalazło się przedstawienie anioła zwiastującego św. Annie. Dalej, w górnym rzędzie, umieszczono scenę, na której anioł nakłania św. Joachima do małżeństwa ze św. Anną. Poniżej namalowane zostało przedstawienie

9 J. i J. Sobaczykowie, op. cit., s. 6.

10 Od 2008 roku w kościele św. Anny w Poznaniu znajduje się poliptykowy ołtarz przeniesiony tu właśnie z kościoła NMP na Ostrowie Tumskim, do którego został zaprojektowany przez Taranczewskiego w połowie lat 50.; [zob.:] Parafia św. Anny w Poznaniu ma już 60 lat, [dokument elektroniczny] tryb dostępu: http://www.archpoznan.pl/index2.php?option $=$ com_content\&task $=$ view\&id $=750 \& p o p=1 \&$ page $=0 \&$ Itemid=121 $(12.05 .2014)$.

11 M. Taranczewska, Kalendarium sycia i twórczośsi Wactawa Taranczenskiego, [w:] Wactaw Taranczenski, red. P. Taranczewski, Kraków 2008, s. 162.=

12 J. i J. Sobaczykowie, op. cit., s. 10. 
św. Joachima dowiadującego się o poczęciu Marii. Pozostałymi obrazami, które znalazły się po lewej stronie prezbiterium, są kolejno scena spotkania św. Anny i św. Joachima przy złotej bramie, przedstawienie narodzin Najświętszej Marii Panny, a także pierwszej drogi Marii do świątyni oraz pretendentów do ręki Marii. Po prawej stronie ołtarza znalazły się natomiast sceny zaślubin Marii ze św. Józefem, zwiastowania Najświętszej Marii Pannie, pokłonu pasterzy, ofiarowania w świątyni, pokłonu Trzech Króli, ucieczki do Egiptu, rzezi niewiniątek oraz przedstawienie dwunastoletniego Jezusa nauczającego w świątyni. Środkowa ściana prezbiterium nie zawierała żadnych dekoracji ${ }^{13}$. Stanowiła jedynie tło dla znajdującego się wówczas w kościele ołtarza głównego, nawiązując kolorystyką do flankujących ja ścian ze scenami figuralnymi.

Powyżej cyklu malowideł w prezbiterium, nad wejściem do zakrystii umieszczone zostało znacznych rozmiarów przedstawienie tronującego Boga Ojca (il. 1) w towarzystwie sześciu aniołów, umieszczonych symetrycznie po trzech z lewej i prawej strony ${ }^{14}$.

Do naw bocznych kościoła Wacław Taranczewski zaprojektował figury dwunastu apostołów (il. 2), a także przedstawienia aniołów, które znajdowały się ponad wejściami na chór ${ }^{15}$. Na ścianach naw bocznych namalowano osiem dekoracyjnych medalionów z biblijnymi motywami. Wśród nich w części kościoła znajdującej się bliżej prezbiterium znalazły się symbole Eucharystii oraz symbole ewangelistów - św. Jana (il. 3) i św. Mateusza. W części bliższej chórowi oraz bezpośrednio nad nim znalazły się natomiast symbole wywyższenia węża miedzianego oraz rajskiego drzewa poznania dobra i zła, a także symbole pozostałych dwóch ewangelistów - św. Marka i św. Mateusza ${ }^{16}$. Zwieńczeniem całej aranżacji nowego malarskiego

13 A. Linertas, Polichromie Wacława Taranczewskiego w Wielkopolsce, praca magisterska pod kier. dra J. Skuratowicza w Zaocznym Studium Wychowania Plastycznego przy PWSSP w Poznaniu, mps w archiwum UAP, Poznań 1978, s. 35.

14 J. Czech [zał.], Biała karta kościoła pw. św. Anny w Poznaniu, Malarstwo ścienne: Bóg Ojciec, w zb. MKZ, Poznań 1994.

15 J. i J. Sobaczykowie, op. cit., s. 10.

16 Ibidem, s. 10. 
wystroju wnętrza były dekoracyjne wici roślinne namalowane przez zespół Taranczewskiego na tle białego sklepienia wzdłuż ceglanych żebrowań ${ }^{17}$.

W 1981 roku, po upływie dwudziestu pięciu lat od powstania polichromii Wacława Taranczewskiego w kościele św. Anny w Poznaniu, malowidła poddano pracom konserwatorskim ${ }^{18}$. Nadzór nad całym procesem powierzono ówczesnemu archidiecezjalnemu konserwatorowi zabytków ks. kanonikowi Stefanowi Tomaszkiewiczowi. Prace wykonać miał natomiast artysta malarz Teodor Szukała ${ }^{19}$.

Przed rokiem 1993 z wnętrza zniknęła część dekoracji, którą znamy już tylko z archiwalnych zdjęć oraz opisów. Fotografie wykonane w latach 1993 i $1994^{20}$ ukazuja wnętrze kościoła pozbawione polichromii na sklepieniach oraz przedstawień dwunastu apostołów, które najpewniej zostały zamalowane. Z części innych polichromii zrezygnowano w latach następnych. Były wśród nich widoczne jeszcze na wspomnianych zdjęciach z lat 90. przedstawienia $\mathrm{w}$ medalionach na ścianach naw oraz wizerunek Boga Ojca w prezbiterium, którego stan określano wówczas jako dobry ${ }^{21}$.

Zachowana część malowideł została poddana gruntownej renowacji po raz drugi w roku 1996. Polichromie „odnowił” profesor Maciej Andrzej Labowski wraz z synem Rafałem ${ }^{22}$. W latach późniejszych miały jeszcze miejsce drobniejsze prace przy cyklu malowideł ilustrujących życie św. Anny i Marii. Wykonane zostały „lokalne reperacje” warstwy malarskiej, polegające na szerokim przemalowaniu jej ubytków.

17 J. Czech [zał.], Biała karta kościoła pw. św. Anny w Poznaniu, Malarstwo ścienne: Sceny z życia św. Anny i Marii, w zb. MKZ, Poznań 1994. Tego typu motyw dekoracyjny na sklepieniu Wacław Taranczewski wielokrotnie wykorzystuje w swoich aranżacjach, choćby w innych poznańskich kościołach - NMP na Śródce, św. Małgorzaty czy św. Marcina.

18 Decyzja o przeprowadzeniu prac konserwatorskich wynikała z postępujących zniszczeń, których przyczynę było wówczas trudno ustalić; [zob.:] A. Linertas, op. cit., s. 39 i 48.

19 J. i J. Sobaczykowie, op. cit., s. 10.

20 Fotografie wykonane zostały przez Piotra Czecha i Jerzego Miecznikowskiego na potrzeby Biura Miejskiego Konserwatora Zabytków w Poznaniu i przechowywane są w jego zbiorach

21 J. Czech [zał.], Biała karta kościoła pw. św. Anny w Poznaniu, Malarstwo ścienne: Bóg Ojciec....

22 Informacja zaczerpnięta z kroniki parafialnej, dzięki życzliwości obecnego proboszcza parafii pw. św. Anny, ks. Marka Balcera. 
Obecnie jedynym zachowanym fragmentem polichromii w kościele pw. św. Anny w Poznaniu jest cykl malowideł znajdujący się w prezbiterium. Jednak jak wiele wspólnego maja polichromie w obecnym stanie $z$ ich pierwotnym wyglądem? Pewne jest, że zostały one poddane interwencjom daleko odbiegającym od dzisiejszego kanonu właściwej konserwacji-restauracji. W konsekwencji wszystkich wcześniejszych zabiegów widzimy dzisiaj na ścianach prezbiterium malowidła Wacława Taranczewskiego całkowicie przemalowane po formie.

Próba zestawienia fotografii tych polichromii z lat 90. z ich dzisiejszym stanem pokazuje wyraźnie, że z biegiem lat traciły one coraz bardziej swój pierwotny charakter (il. 5, 6 i 7). Choć dysponujemy czarno-białymi zdjęciami malowideł, nie sposób nie zauważyć znaczacych zmian, jakie zaszły w nich w ciagu tych ostatnich dwudziestu lat. Widzimy, jak przemianie uległ sposób opracowania płaszczyzn barwnych oraz ich natężenie. Zmiany zaszły również w konturach postaci, które gdzieniegdzie odbiegały od swojego pierwowzoru, a czasami po prostu zanikały. Deformacje te szczególnie uwidaczniają się w charakterze rysów twarzy. Ponadto zaobserwować można, że malowidła straciły swoją lekkość, którą zawdzięczały wyraźnie uczytelniającej się fakturze podłoża, zagubionej w późniejszych latach pod stosunkowo grubą warstwą przemalowania.

Archiwalne zdjęcia ilustrują również zakres zniszczeń, jakie w tamtym czasie postępowały w malowidłach. Widoczne są liczne ubytki oraz przetarcia warstwy malarskiej, wskazujące na istniejący już wtedy problem degradacji spoiwa.

\section{Analiza stanu zachowania oraz identyfikacja czynników niszczących}

Określenie stanu zachowania polichromii w kościele pw. św. Anny w Poznaniu rozpoczęto od wizualnej analizy w świetle widzialnym rozproszonym i skośnym. Potwierdziło to kilkukrotne poddanie malowideł niefachowym pracom renowacyjnym w przeszłości. Nie doszłoby do nich jednak, gdyby oryginalna warstwa polichromii zachowywała się w dobrym stanie. Już wstępna analiza wskazywała na utratę spoiwa w tej warstwie. Rodzi się za- 
tem pytanie, co było tego przyczyną - nieodpowiednie warunki dla zastosowanej techniki malarskiej, powodujące np. wypłukanie spoiwa lub jego biologiczny rozkład, czy może był to błąd technologiczny, a więc przyczyna istniejąca już w momencie powstania dzieła?

Wykonane w przeszłości zabiegi „pseudokonserwatorskie” przyczyniły się w kolejnych latach do dodatkowego pogorszenia stanu malowideł. Choć zamysł tamtych prac był zapewne inny i z pewnością wykonano je w dobrej wierze, obecnie warstwa gruntownego przemalowania jest jedna z przyczyn bardzo szybko postępującej destrukcji. Jest to logicznym następstwem przykrycia osłabionych, pudrujących się warstw oryginalnych nowa, szczelną warstwą o stosunkowo mocnym spoiwie. Dzisiaj znaczna powierzchnia wtórnych warstw malarskich pokryta jest siatką spękań wraz z podnoszącymi się łuskami, które odpadając, zrywają ze sobą również leżący pod spodem oryginał (il. 8 i 9).

W celu określenia przyczyny złego stanu zachowania malowideł niezbędne było zidentyfikowanie czynników odpowiedzialnych za brak adhezji i kohezji w warstwie oryginalnej. Nie bez znaczenia był również wpływ czynników niszczących na wtórne warstwy malowidła, dlatego do zagadnienia należało podejść wielopoziomowo. Bezpośrednich i pośrednich przyczyn postępującej przez lata destrukcji szukano zarówno w strukturze polichromii, podłoża, na którym leżą, jak i w ich otoczeniu.

Szczegółowej analizie pod katem poszukiwań przyczyn niszczenia malowideł poddano zarówno ich warstwy stratygraficzne, jak i warunki klimatyczne panujące wewnątrz kościoła - wilgotność względną i temperaturę powietrza, temperaturę oraz wilgotność bezwzględną murów. Wykonane zostały także badania mikrobiologiczne.

\section{Analiza stratygrafii malowideł}

Przekroje poprzeczne próbek pobranych z wybranych miejsc polichromii doskonale ilustrują złożona stratygrafię malowideł. W przypadku ich poszczególnych fragmentów obserwujemy zróżnicowaną liczbę warstw malarskich. Potwierdza to przeprowadzenie w przeszłości wielokrotnych prac renowacyjnych, polegających na przemalowaniu powierzchni polichromii nową warstwa farby, przeważnie przy zachowaniu ogólnego koloru, ale w tonie i odcieniu 
niezbyt wiernym oryginałowi ${ }^{23}$. Dodatkowo zdywersyfikowana liczba warstw na różnych fragmentach malowideł pokazuje, że nie każda z poszczególnych ingerencji dotyczyła całej ich płaszczyzny. $Z$ tego właśnie powodu na przekroju stratygraficznym próbki pobranej z zielonej szaty postaci widzimy trzy warstwy malarskie (il. 10), a w przypadku próbki pobranej z żółtej ramy otaczającej poszczególne sceny takich warstw widzimy aż sześć (il. 11).

Przeprowadzone badania składu chemicznego poszczególnych warstw polichromii wykazały obecność spoiw organicznych.

\section{Badania mikrobiologiczne}

W celu jednoznacznego stwierdzenia lub wykluczenia obecności drobnoustrojów, które mogłyby w przeszłości stać się przyczyną daleko posuniętych, niefachowych ingerencji oraz które mogłyby stanowić jedną z przyczyn obecnego złego stanu zachowania malowideł, konieczne było wykonanie specjalistycznych badań ${ }^{24}$. Z powierzchni polichromii pobrany został materiał do badań laboratoryjnych i analizy metodą obrazowania skaningowego (SEM) ${ }^{25}$. Wykonano kontrolę powierzchni lumenometryczna metoda polegająca na oznaczeniu Adenozynotrifosforanu (ATP $)^{26}$, do której pobrano wymazy z wytypowanych fragmentów malowideł.

Wyniki przeprowadzonych testów ATP dały niejednoznaczne rezultaty, wskazując na bardzo duże stężenie drobnoustrojów tylko w przypadku dwóch z czterech poddanych badaniu miejsc (tab. 1). W przypadku dwóch pozostałych badanie wykazało wysokość stężenia drobnoustrojów na poziomie akceptowalnym dla malowideł ściennych. Dysonans w wynikach ATP pomiędzy wymazami pobranymi z jednego obiektu wynikać

23 Warstwa o oranżowym odcieniu, widoczna na il. 10, leżąca pod warstwami zielonymi stanowi oryginalne, jednolite podmalowanie pod całe pola przedstawień figuralnych. Szczegółowe dane dotyczące sposobu opracowania poszczególnych warstw malowideł, ich techniki i technologii, stanowią osobne zagadnienie, które szczegółowo opracowywane zostaje w oddzielnym artykule.

${ }^{24}$ Wykonanie badań mikrobiologicznych i analiza wyników przy współpracy z dr J. Karbowską-Berent i mgr J. Jarmiłko.

25 Badania wykonano za pomoca skaningowego mikroskopu elektronowego Quanta 3D FEG z użyciem detektora SE.

26 Badania ATP przeprowadzone za pomoca zestawu do kontroli powierzchni HY-LiTE. 
może np. z występowania lokalnego, skumulowanego zanieczyszczenia powierzchniowego. Takie rezultaty nie pozwalaja jednoznacznie potwierdzić lub wykluczyć występowania w strukturze malowideł drobnoustrojów odpowiedzialnych za ich niszczenie.

Tab. 1. Wyniki badań ATP

\begin{tabular}{|c|l|c|l|}
\hline $\begin{array}{c}\text { Oznaczenie } \\
\text { próbki }\end{array}$ & \multicolumn{1}{|c|}{ Miejsce pobrania wymazu } & Wynik badania ATP & \multicolumn{1}{|c|}{ Interpretacja wyniku } \\
\hline A.1 & błękitne tło sceny ucieczki do Egiptu & 770 & w normie \\
\hline A.2 & żółta rama okalająca sceny & 78000 & znacznie powyżej normy \\
\hline A.3 & $\begin{array}{l}\text { szara noga owcy ze sceny obwieszczenia } \\
\text { św. Joachimowi poczęcia Marii }\end{array}$ & 2900 & w normie \\
\hline A.4 & żótta rama okalająca sceny & 89000 & znacznie powyżej normy \\
\hline
\end{tabular}

Występowanie czynnika mikrobiologicznego w procesie niszczenia analizowanych polichromii potwierdziło jednak ostatecznie badanie metodą SEM, któremu poddano kolejne cztery próbki pobrane z powierzchni malowideł. Analiza obrazu uzyskanego po napyleniu próbek złotem w celu uzyskania precyzyjniejszego obrazu pod skaningowym mikroskopem elektronowym pozwoliła na dokładne zlokalizowanie drobnoustrojów.

Zaobserwowane strzępki grzybów wyraźnie przerastają jedynie pierwotną warstwę malowideł (il. 12 i 13). Nie są natomiast widoczne we wtórnych warstwach stratygraficznych polichromii. Nie udało się także zaobserwować zarodników grzybów, które towarzyszyłyby widocznym strzępkom. Wskazywać to może na użycie farby zainfekowanej tymi drobnoustrojami już w trakcie nanoszenia jej na ścianę, a także na to, że obecnie drobnoustroje te moga być już nieaktywne.

\section{Badania wilgotności murów}

Pomiary wilgotności murów ${ }^{27} \mathrm{w}$ prezbiterium, zarówno na powierzchni badanych malowideł, jak i poniżej poziomu ich wysokości, a także w ścianach

\footnotetext{
27 Pomiary wilgotności murów wykonane zostały za pomoca wilgotnościomierza podłoża WCP-16.
} 
naw kościoła wykazały wilgotność na poziomie 2-3\%. Przeprowadzone badania wilgotności bezwzględnej w murach świątyni nie wykazały zatem istniejących obecnie odchyleń od przyjętych norm. Tym samym wykluczono zawilgocenie ścian jako jedna z aktywnych przyczyn niszczenia badanych malowideł.

\section{Badania klimatyczne}

Badania klimatu panującego w kościele św. Anny w Poznaniu oraz czynników mających wpływ na jego kształtowanie się we wnętrzu prowadzone były w trzech okresach pomiarowych ${ }^{28}$. Pierwszy z nich trwał od 15 grudnia 2012 do 28 lutego 2013 roku, drugi od 8 marca do 22 maja 2013 roku, ostatni natomiast od 29 czerwca do 10 sierpnia 2013 roku. Okresy te miały uwzględniać pory roku najbardziej newralgiczne dla warunków klimatycznych użytkowanych wnętrz kościelnych, takie jak okres Bożego Narodzenia, wiosenne przesilenia pogodowe oraz wysokie temperatury letnie. W kościele umieszczono dwa termohigrometry, z których jeden dokonywał pomiarów w bezpośrednim sąsiedztwie malowideł w prezbiterium, a drugi na chórze, po przeciwległej stronie kościoła. Trzeci termohigrometr umieszczony został na elewacji plebanii, w odległości ok. 25 metrów od murów świątyni, w celu rejestrowania zewnętrznych warunków klimatycznych. Ponadto w prezbiterium umieszczono pirometr, który monitorował temperaturę środkowej ściany prezbiterium przylegającej do polichromii Taranczewskiego ${ }^{29}$. Po każdym z trzech okresów pomiarowych dane z rejestratorów przetwarzane były za pomoca specjalistycznego oprogramowania, co pozwoliło na dokonanie bardzo szczegółowej analizy warunków klimatycznych panujących wewnątrz świątyni.

28 Badania oraz analiza pozyskanych wyników przy wspólpracy z prof. dr kwal. II stopnia B. J. Roubą oraz mgr M. Kapką mgr B. Gmińskią-Nowak i mgr I. Jabłońska; metodyka tych badań oraz warunki klimatyczne kościoła św. Anny w Poznaniu zostają szerzej omówione w artykule poświęconym wyłącznie zagadnieniom parametrów klimatu tejże świątyni.

${ }^{29}$ Do rejestracji parametrów wykorzystano termohigrometry oraz pirometr firmy LAB-EL. 
Szczególnie cenne okazuje się zestawienie ze sobą danych z zimowego okresu pomiarowego - kiedy uruchamiany jest w kościele system grzewczy, z danymi z okresu późnowiosennego i letniego, kiedy nie ma potrzeby ogrzewania wnętrza. Wpływ ogrzewania, a także parametry klimatu zewnętrznego na kształtowanie się wysokości temperatury i wilgotności powietrza wewnątrz świątyni obrazują wykresy wygenerowane z pozyskanych danych.

Analiza danych wskazuje na mocne rozchwianie warunków klimatycznych we wnętrzu kościoła w okresie zimowym (il. 14), co spowodowane jest głównie funkcjonującym obecnie w świątyni systemem ogrzewania nawiewowego ${ }^{30}$. Uruchamiany jest on średnio 30 minut przed zgromadzeniami wiernych i wyłączany po zakończeniu nabożeństw. Obserwujemy towarzyszące temu gwałtowne zmiany temperatury i wilgotności powietrza, które powtarzając się regularnie, mogą stanowić duże zagrożenie dla stanu zachowania malowideł ściennych.

Przyglądając się danym pozyskanym poza okresem grzewczym, zauważamy, że warunki klimatyczne we wnętrzu stabilizują się (il. 15). Wykazują jedynie niewielkie zmiany swoich parametrów w stosunku do tych, które obserwowaliśmy podczas analizy danych z okresu zimowego. Sa one zależne w większym stopniu od wysokości temperatury i wilgotności powietrza na zewnątrz oraz od obecności zgromadzonych w kościele wiernych. Zmiany te sa na tyle łagodne i rozciagnięte w czasie, że nie powinny stanowić zagrożenia dla polichromii Taranczewskiego.

Zbiór danych pozyskanych za pomocą termohigrometrów i pirometru pozwolił dodatkowo na określenie punktu rosy dla wnętrza kościoła. Analiza wyników dowiodła, że w trakcie prowadzonych pomiarów nie dochodziło do kondensacji pary wodnej. Dane wskazują, iż nawet przy dużych zmianach parametrów klimatu w świątyni temperatura punktu rosy utrzymywała się na wysokości bezpiecznej dla malowideł.

30 System ten funkcjonuje w kościele od 2008 roku; informacja uzyskana podczas wywiadu z pełniącym w parafii funkcję kościelnego panem Sebastianem Ignaszakiem, potwierdzona widniejącą na piecu nalepką z datą montażu. 


\section{Podsumowanie wyników}

Przedstawione rezultaty badań, analiza stanu zachowania i historii malowideł Wacława Taranczewskiego w kościele pw. św. Anny w Poznaniu wskazuja główne przyczyny postępujących w nich obecnie zniszczeń.

Najważniejszą przyczyna niszczenia polichromii na przestrzeni ostatnich trzydziestu lat była najprawdopodobniej utrata spoiwa w warstwie oryginalnej na skutek zainfekowania jej przez drobnoustroje. Sytuacje pogorszyły następujące po sobie w ciagu kolejnych lat nieprofesjonalne prace renowacyjne. Nie tylko nie zlikwidowały one pierwotnej przyczyny postępującej destrukcji, ale dodatkowo wzmagały procesy niszczenia.

W ciagu kilku minionych lat degradacja polichromii mogła ulec intensyfikacji na skutek zainstalowania w kościele nowego systemu ogrzewania. Ma on znaczący wpływ na klimat we wnętrzu świątyni w trakcie kilkumiesięcznego okresu grzewczego. Gwałtowne zmiany temperatury oraz wilgotności powietrza w otoczeniu malowideł moga stanowić zagrożenie poprzez dodatkowe wzmaganie naprzemiennego pęcznienia i kurczenia się spoiwa w szczelnych warstwach przemalowania.

\section{Wnioski końcowe}

Obecny stan malowideł Wacława Taranczewskiego w kościele pw. św. Anny w Poznaniu jest skutkiem piętrzących się z biegiem lat problemów. W trakcie szczegółowej analizy przyczyn tego stanu wysuwają się na pierwszy plan dwa główne czynniki. Pierwszym z nich są drobnoustroje, które zainfekowały oryginalną warstwę malarską i przyczyniły się do utraty jej spoiwa, powodując w następstwie osłabienie jej adhezji i kohezji oraz osypywanie się pigmentów. Drugim czynnikiem jest czynnik ludzki - nadrzędny w stosunku do wynikających z niego kolejnych przyczyn niszczenia malowideł, takich jak warstwa szczelnych przemalowań. To właśnie nieodpowiednie postępowanie $z$ wartościową materią artystyczną doprowadziło do kolejnych, nieprofesjonalnych prób „ratowania Taranczewskiego” w kościele św. 
Anny, które zamiast zamierzonego rezultatu poprawy stanu malowideł, doprowadziły w kolejnych latach do znacznego pogłębienia stopnia zniszczeń.

Właściwym postępowaniem w przypadku stwierdzenia w malowidłach ściennych mikroorganizmów niszczących ich strukturę jest przede wszystkim zatrzymanie postępujących procesów destrukcji. W dalszej kolejności należy zatroszczyć się o przywrócenie właściwej dla takich polichromii kohezji i adhezji.

Oba te zabiegi w przypadku malowideł w poznańskim kościele św. Anny będą z pewnością mocno utrudnione z powodu przemalowań, które szczelnie przykrywaja warstwy oryginalne. Bez wykonania tych zabiegów nie będzie można jednak przystapić do jakichkolwiek dalszych prac. Dopiero po przeprowadzeniu dezynfekcji i konsolidacji oryginalnej warstwy malarskiej polichromii można będzie rozważyć wykonanie następnych zabiegów, takich jak usunięcie wtórnych nawarstwień i uzupełnienie ubytków w oryginalnej warstwie malowidel ${ }^{31}$.

Polichromie Wacława Taranczewskiego w kościele pw. św. Anny w Poznaniu z pewnością warte są otoczenia ich odpowiednią opieka, która pozwoli zachować je w dobrym stanie dla następnych pokoleń. Bez wattpienia stanowią również ogromne wyzwanie dla współczesnego konserwatora dzieł sztuki, który tą opieką musi je otoczyć.

\section{Summary}

\section{The outline of history, state of preservation} and damages causes of mural paintings by Wacław Taranczewski in the church of St. Anna in Poznan

The aim of this article is to present the history of mural paintings by Wacław Taranczewski in the church of St. Anna in Poznań, particularly in relation to un-

\footnotetext{
31 Trudności w przenikaniu środków konsolidujących i dezynfekujących przez szczelne warstwy przemalowań potwierdzone zostały próbami in situ przeprowadzonymi na potrzeby przygotowywanej przez autorkę rozprawy doktorskiej pod kier. prof. nadzw. dr hab. R. Rogala, która poświęcona jest konserwatorskim i technologicznym zagadnieniom malowideł ściennych Wacława Taranczewskiego, w IZK Wydziału Sztuk Pięknych, UMK w Toruniu. W ramach dysertacji szczegółowo opracowana zostaje metodyka postępowania konserwatorskiego dla polichromii w kościele pw. św. Anny w Poznaniu.
} 
professional restoration interventions which were applied in the past and which have contributed to the present polychromy's state of preservation.

Analysis of this state allowed to identify causes that have direct and indirect impact on it. A number of examinations was applied, including studies of microbiological and climatic conditions, and then used to determine destructive factors present in the structure of these paintings and in their environment. A detailed diagnosis of these factors was then presented and the proper methodology to stop progressive destructive processes was briefly outlined. 


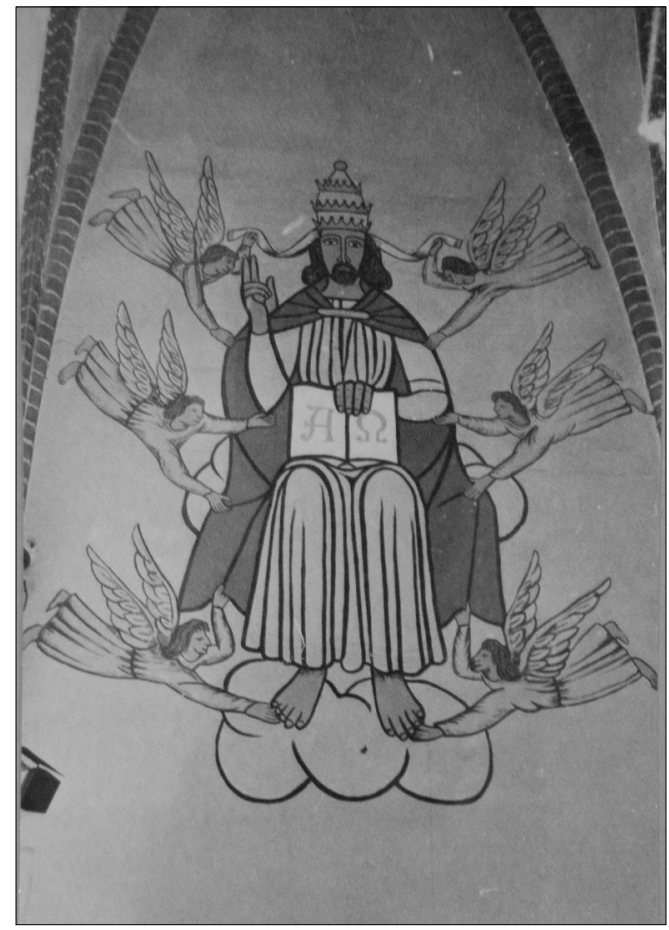

Fot. 1. Przedstawienie Boga Ojca na południowo-zachodniej ścianie prezbiterium, nad wejściem do zakrystii, 1994 r. Fot. P. Czech, ze zb. MKZ w Poznaniu 


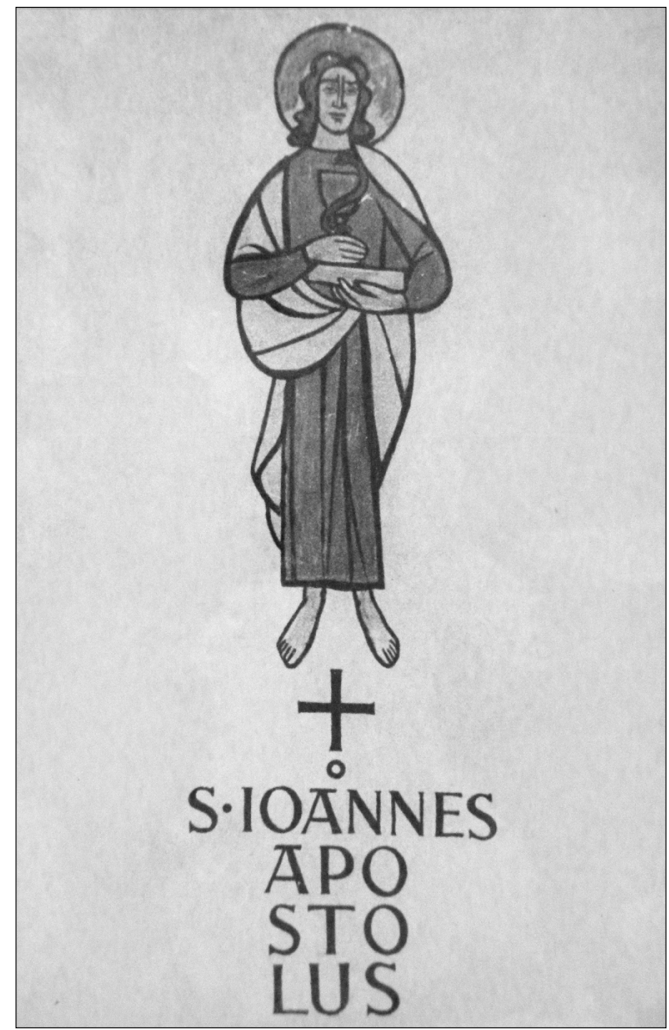

Fot. 2. Reprodukcja fotografii z albumu parafialnego przedstawiającego św. Jana Ewangelistę, 1994 r. Repr. J. Miecznikowski, ze zb. MKZ w Poznaniu 


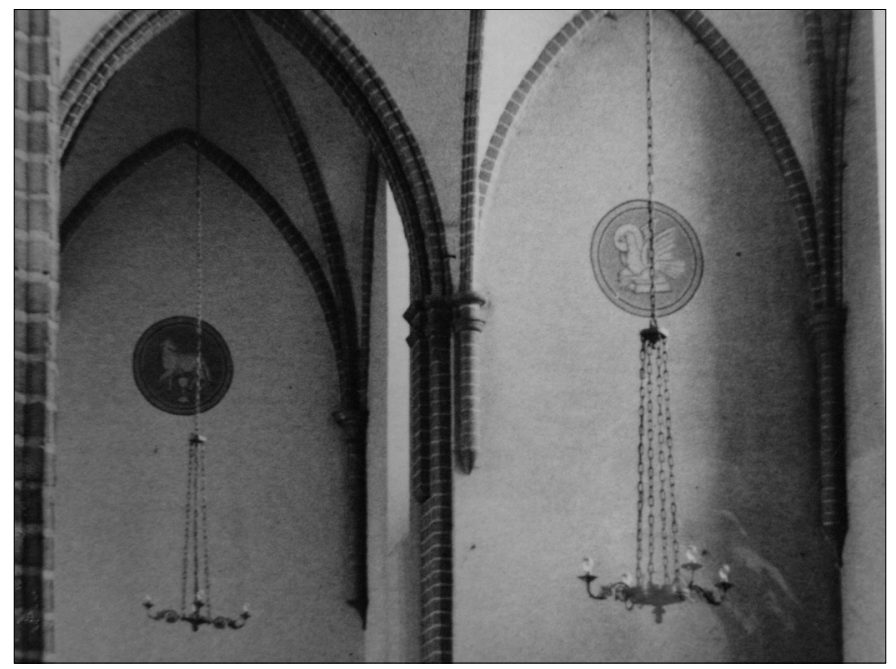

Fot. 3. Przedstawienie sakramentu Eucharystii i symbolu św. Jana Ewangelisty na ścianach nawy północno-wschodniej, 1994 r. Fot. P. Czech, ze zb. MKZ w Poznaniu

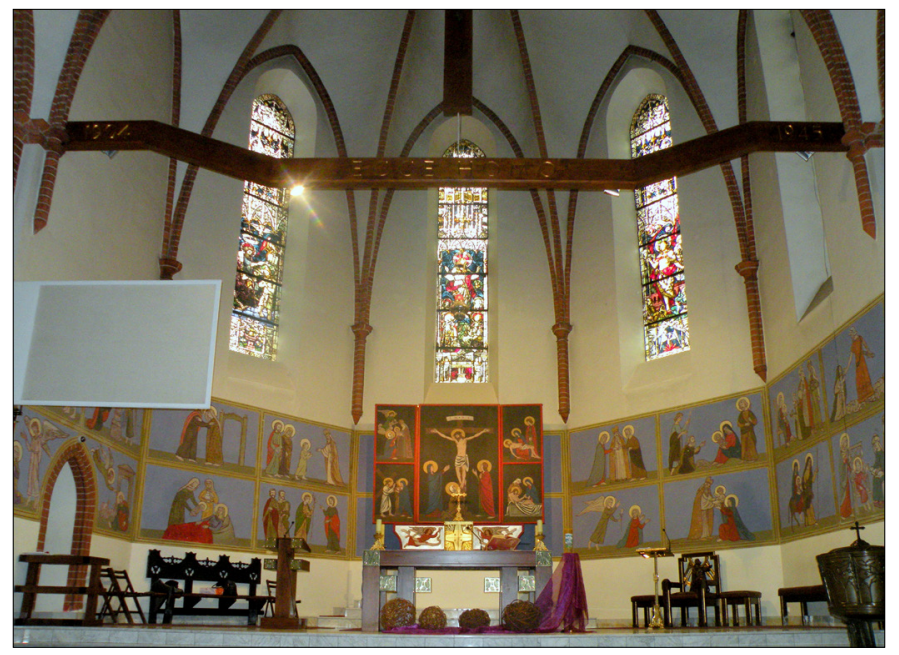

Fot. 4. Obecny widok na prezbiterium kościoła pw. św. Anny w Poznaniu. Fot. A. Lament 


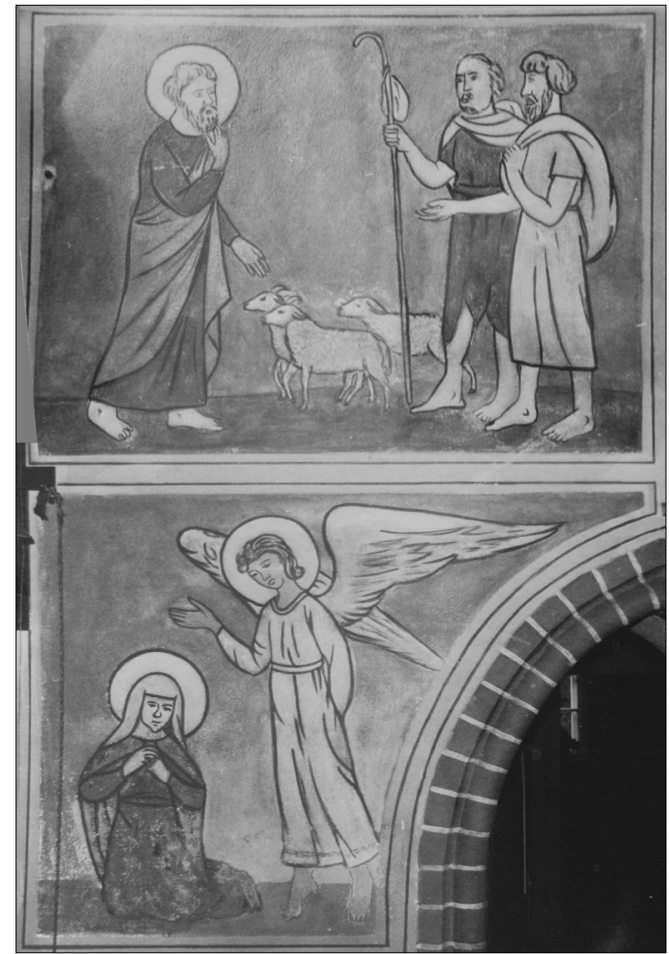

Fot. 5. Dwie pierwsze sceny malowideł w prezbiterium: „Św. Joachim z pasterzami” oraz „Anioł zwiastujący św. Annie” w roku 1994. Widoczny zły stan zachowania: przetarcia, ubytki warstwy malarskiej. Fot. P. Czech, ze zb. MKZ w Poznaniu 


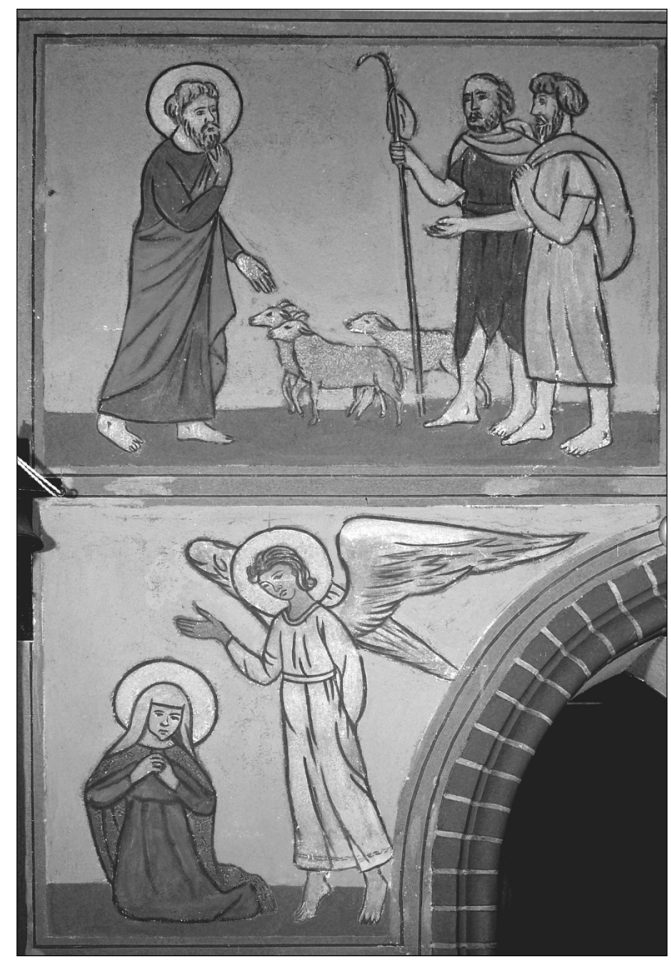

Fot. 6. Stan obecny. Dla ułatwienia analizy zdjęcie pozbawione kolorów - wyraźnie widoczne zmiany w natężeniu tonalnym poszczególnych fragmentów malowidła, w sposobie opracowania płaszczyzn barwnych oraz pewne zmiany prowadzenia konturu. Fot. A. Cupa 
[608]

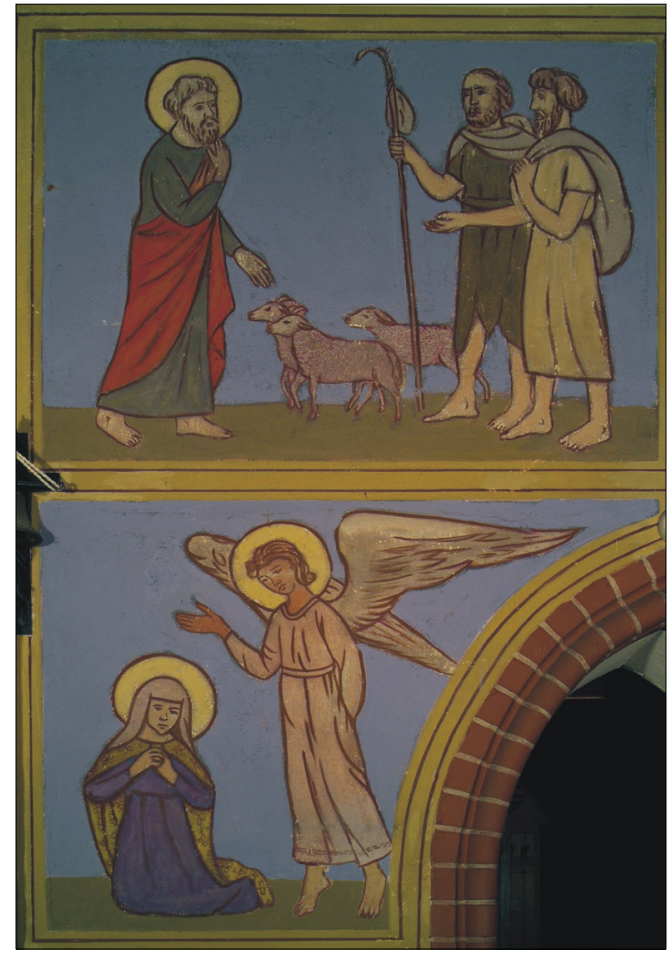

Fot. 7. Stan obecny, zdjęcie w kolorze. Fot. A. Cupa 


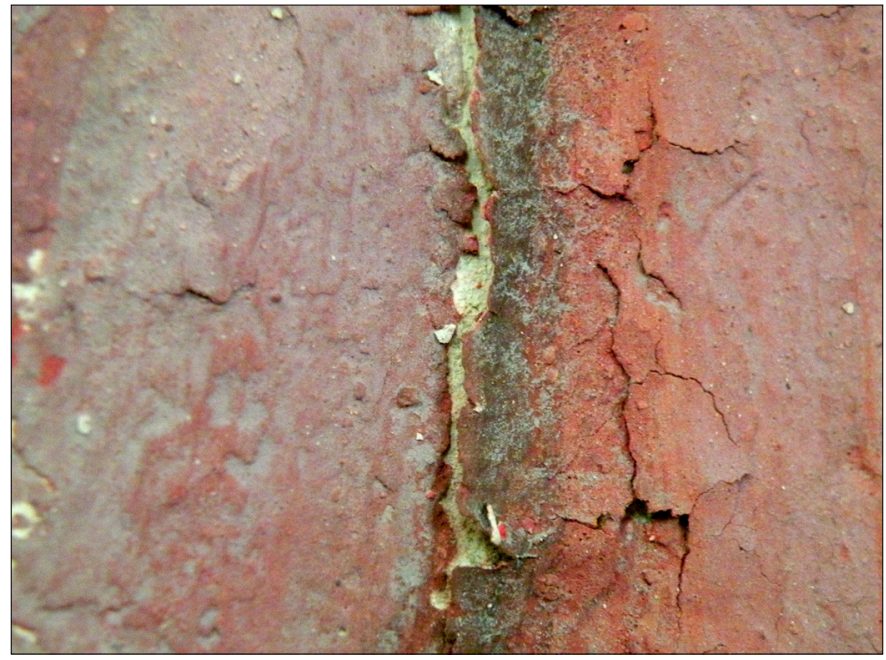

Fot. 8. Fragment szaty św. Anny ze sceny przedstawiającej narodziny Najświętszej Marii Panny. Siatka spękań w warstwach wtórnych tworzy podnoszące się łuski. Fot. A. Lament

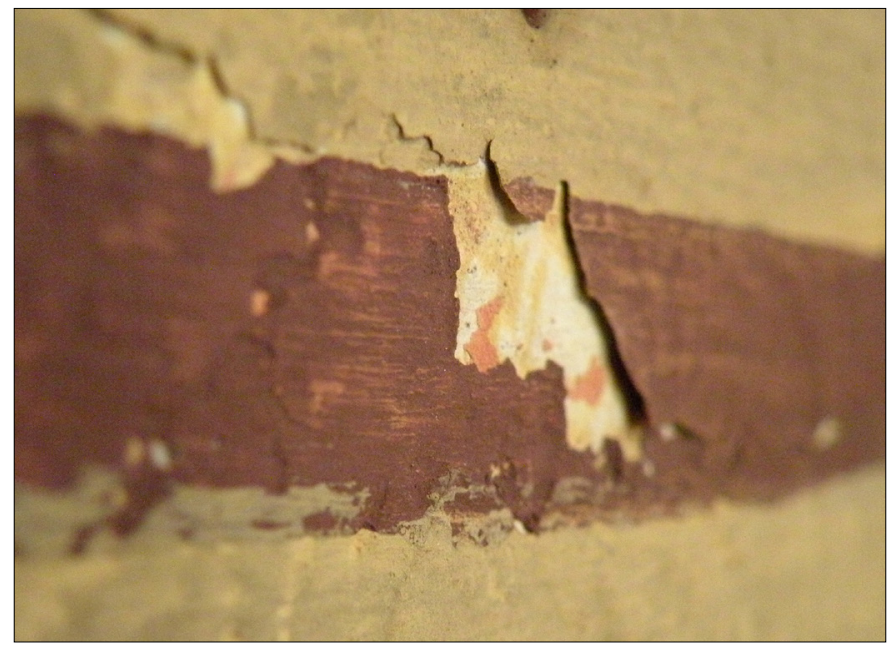

Fot. 9. Fragment ramy okalającej poszczególne sceny malowideł. Widoczny ubytek powstały na skutek odpadnięcia łuski warstwy przemalowania, która zerwała ze sobą osłabioną oryginalną warstwę malarska. Fot. A. Lament 
[610]

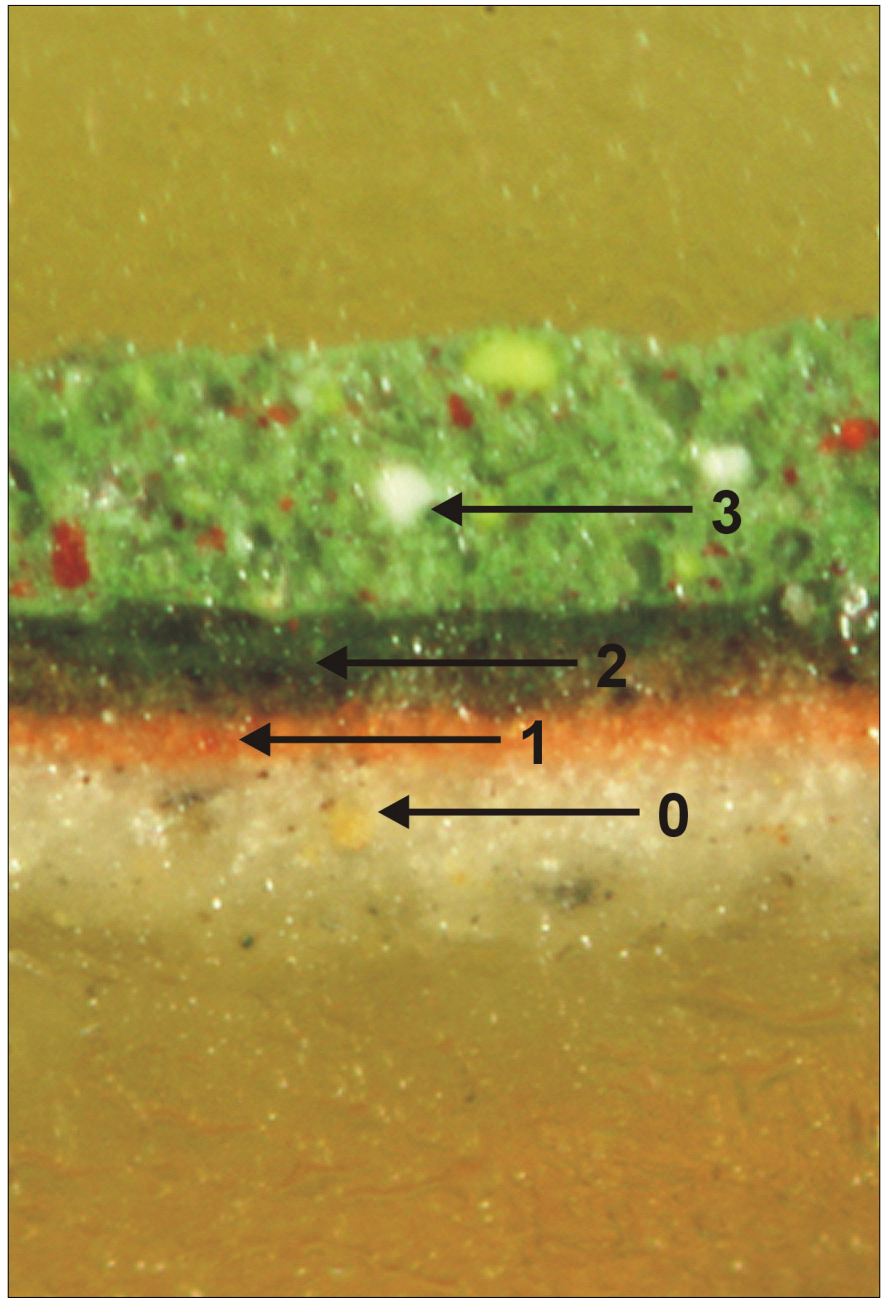

Fot. 10. Przekrój stratygraficzny próbki warstwy malarskiej z szaty św. Józefa, w powiększeniu x 40, pobranej ze sceny przedstawiającej św. Józefa proszącego o rękę Marii. Numerami od 1 do 3 oznaczono leżące na sobie warstwy malarskie, numerem 0 - pobiałę wapienna. Fot. A. Lament 


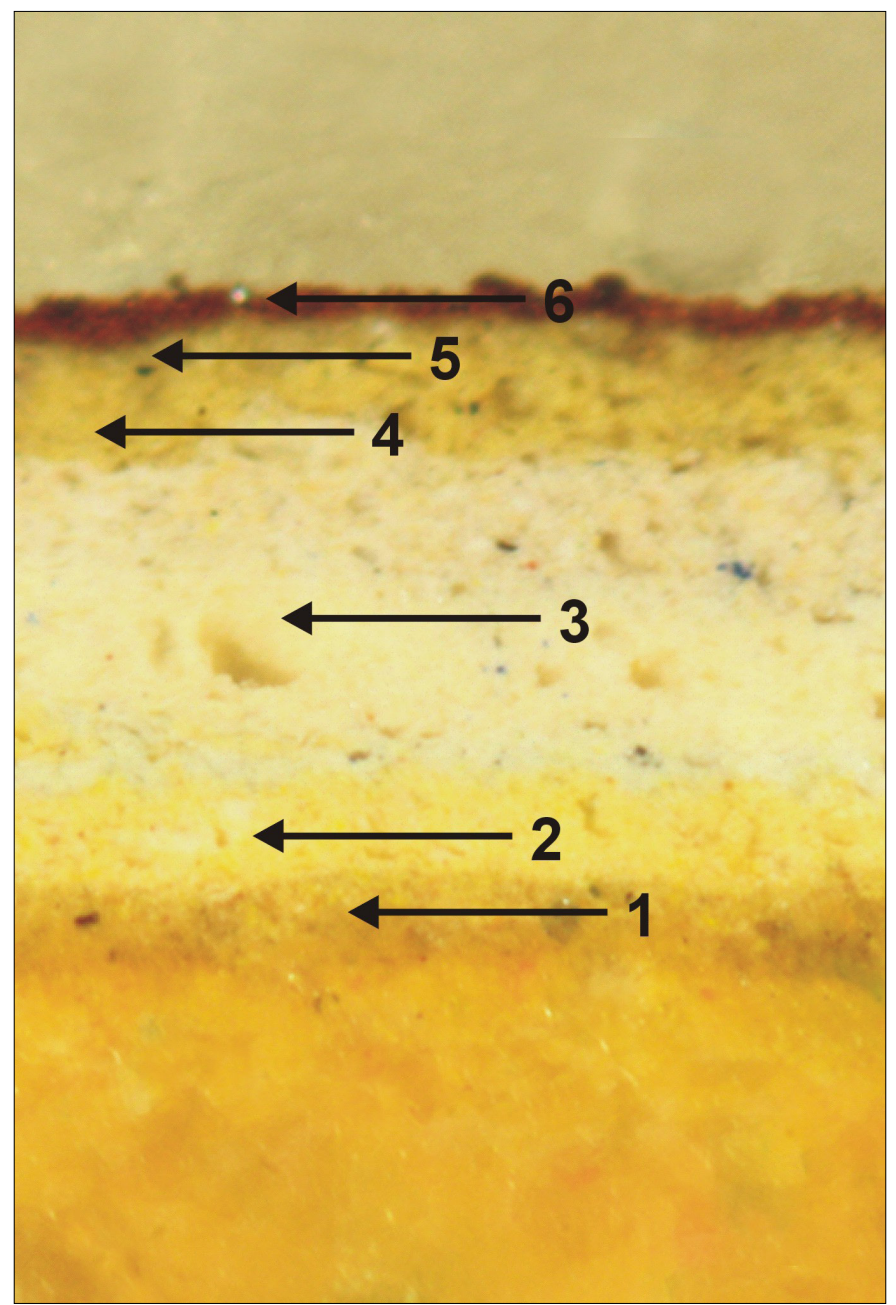

Fot. 11. Przekrój stratygraficzny próbki warstwy malarskiej z ramy okalającej poszczególne sceny malowideł w powiększeniu x 40 . Numerami od 1 do 6 oznaczono leżące na sobie warstwy malarskie. Fot. A. Lament 


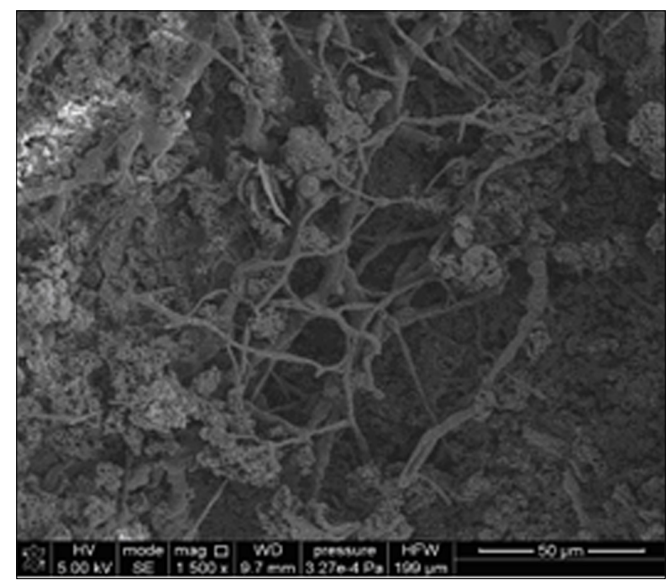

Fot. 12. Próbka pobrana z żółtej ramy sceny przedstawiającej św. Józefa proszącego o rękę Marii. Zdjęcie wykonane podczas badania SEM w powiększeniu x 1500. Zaobserwowane strzępki wyraźnie przerastają tylko pierwotną warstwę malowideł. Fot. D. Kaczor

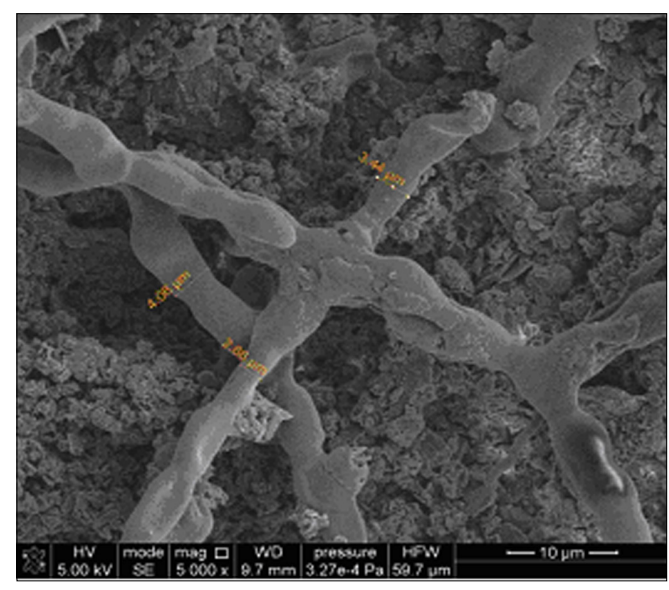

Fot. 13. Zdjęcie tego samego fragmentu, powiększenie x 5000 - wymiary zaobserwowanych tworów (od ok. 2,5 do ok. $5 \mu \mathrm{m}$ ) odpowiadaja grubości strzępków grzybów spotykanych w innych obiektach zabytkowych. Fot. D. Kaczor 


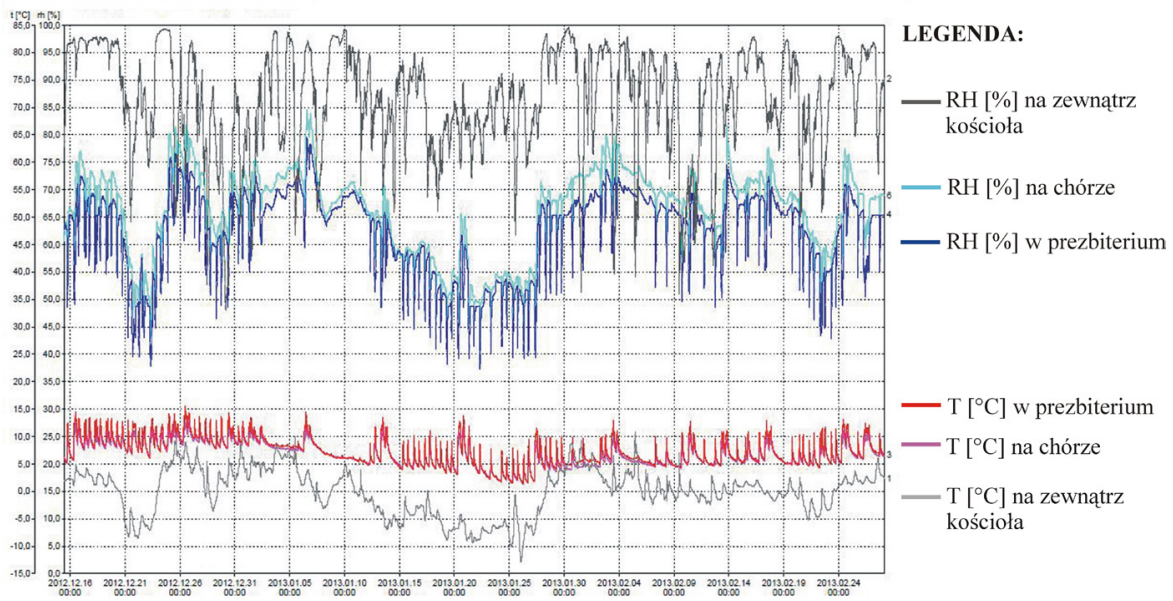

Wykres 1. Zestawienie parametrów klimatu wewnątrz świątyni na tle klimatu zewnętrznego w dn. 15.12.2012-28.02.2013 r.

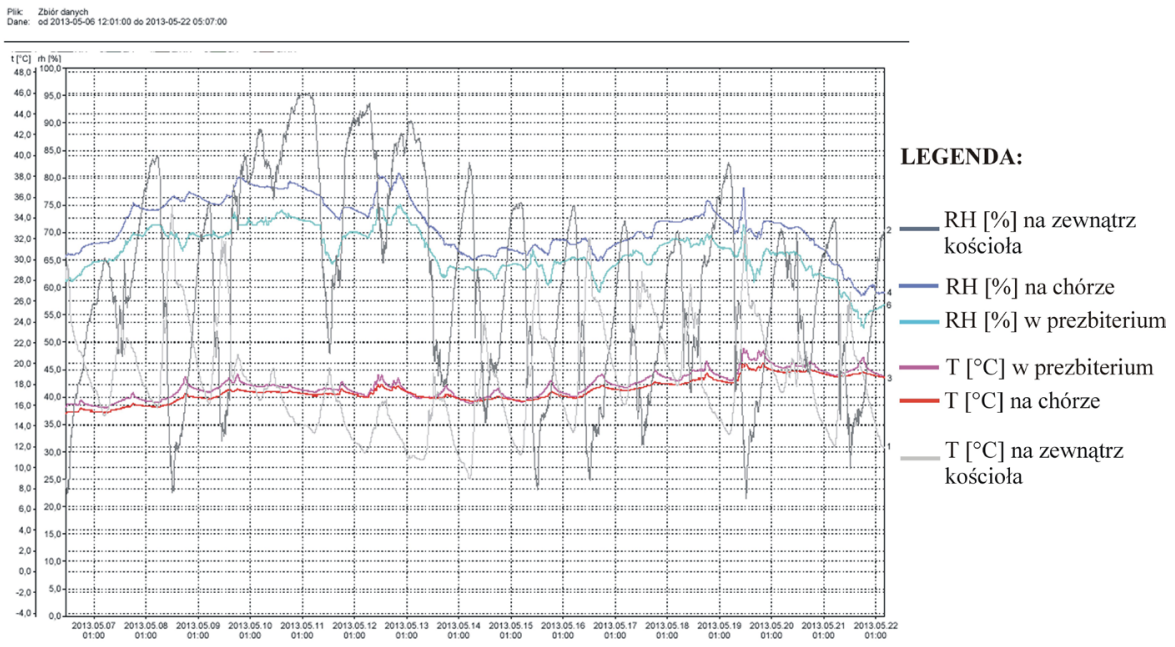

Wykres 2. Zestawienie parametrów klimatu wewnątrz świątyni na tle klimatu zewnętrznego w dn. 6.05-22.05.2013 r. 